\title{
Study on Semantic Change of the Word "Kent" in Uyghur Language*
}

\author{
Buhailiqiemu Halike \\ School of Uyghur Language and Culture \\ Northwest Minzu University \\ Lanzhou, China 730030
}

\author{
Wusiman Jumai** \\ School of Uyghur Language and Culture \\ Northwest Minzu University \\ Lanzhou, China 730030 \\ **Corresponding Author
}

\begin{abstract}
The semantic change of the word "kent" took place in the long history from the Old Uyghur Language period to the Modern Uyghur Language period. In this paper, the author discusses and analyzes the historical evolution and use of the word "kent" from the perspective of historical linguistics.
\end{abstract}

\section{Keywords-kent; geographical name; semantic change}

\section{INTRODUCTION}

In modern Uyghur language, semantic change has shown its influence in many words with the development of society. Meanings of some words have been expanded, that of some narrowed, and some words have been replaced by other words. In this paper, the author analyzes the use and semantic change of Kant, a word in Old Uygur Language. This paper mainly takes the geographical names that take "kent" as the core in central Asia since the formation of written literature as the research object.

From the perspective of the development of written literature, the word "kent" we are going to discuss today has experienced the process of expressing the meanings of town, country and village. The word "känt" originally expressed the meanings of village, city and villagers. Since the inscription literature came out in ancient times, it has been evolving, and it owns different writing forms and meanings in different periods.

\section{The Word "BALIQ" Which Means "City" In Old UYGHUR LANGUAGE}

The word "känt" has been constantly evolving in the historical development, and the form of "baliq" appeared in the inscription literature. The word "baliq" is a pure Uighur word that means "city wall" and "city". In the inscription literature in the seventh century, the word "baliq" means "city, village, place where people live" and so on. The socalled "balïq" here is equivalent to the "känt" in medieval literature, which means "city, castle, grass and swamp, soil"

*This paper is a phased achievement of the central university specia fund project of Northwest Minzu University of the first-level discipline of "Chinese language and literature" --Arrangement and Analysis of Babur Works (Risale-I Aruz manual) (31920180018) and Uygur Literature Research of Chaghatay (319201808112). and so on. ${ }^{1}$

From the above examples, it can be seen that the word "baliq" recorded in the inscription documents means town, region, county, tribe and so on. The following is the geographical names that are relative to balï as recorded in the inscription literature: (1) bäš balïq (pentapolis, Belger Khan Inscription east side, p135); (2) toyu balïq (TugleBaliq, Belger Khan Inscription east side, p136); (3) bay baliq (Fat City, Belger Khan Inscription east side, p263); (4) čanbalïq. (Canbaliq, page 95 in volume One of The Encyclopedia of Turk Ethnic Group Languages; page 621 of The History of Reside, "janbalïq", when Kushluk steadily sat on the throne of Harar Khitan, he engaged in a battle with Gerhan at Zambali for several times, page 400); (6) bäšbaliq (pentapolis, Basbaliq, page 95 in volume One of The Encyclopedia of Turk Ethnic Group Languages; it can be seen twice in The History of Reside. When Jenghiz Khan led his ever-victorious army to the countries of the East, the son of Taiyo Khan, Kushluk, fled to the country Gherhan by the way of Beshbali, page 398).

The word "balïq" recorded in The Encyclopedia of Turk Ethnic Group Languages written in the 11th century means "city" and "castle" in the language of the Altaic language family before Islam. Therefore, it can be seen from The Encyclopedia of Turk Ethnic Group Languages that, "pentapolis (bäsbalïq)" was the largest city of Uighurs. Another city is "yangi balïq", which means "new city". In modern Turkic language, the words which represent the meaning of city such as "balïq" and "känt" are quite common. In Mahmud - Kashkari's masterpiece The Encyclopedia of Turk Ethnic Group Languages, some words in Algoo language and the language of some Uguz tribes that were of the same usage as "balïq" were also recorded.

From the "inscription literature" that starts literature, to the large-scale encyclopedia The Encyclopedia of Turk Ethnic Group Languages which came to be a book that is able to reveal the customs, geographical environment and language habits of various ethnic groups in Central Asia at that time, the word "baliq" had been used to expresses the meaning of "city". In the historical development over the

Dictionary of Old Uighur: Xinjiang Juvenile Publishing House, 1st edition published in January, 1989, page 85. 
centuries, the word "balï" has a wide range of application, and it is used to mean "city, hometown, native place". Today, some territory names that take "balïq" as the main part still exist in some regions of Kashgar. It is recorded that today's "Hami" was once named as "Qamul balïq".

\section{THE WORD "Ulus" THAT Is USED TO EXPRESS THE MEANING OF "CITY"}

In another classic book Kutadgu Bilig that was written 30 to 40 years later than The Encyclopedia of Turk Ethnic Group Languages, "ulus" was used to express the meaning of "city". For example,

Each city, each village, each court offers this book a different name. ${ }^{2}$

‘qayu känd,ulus, ordu-qarši yärdä

\section{kätabqa öngin at atamišlar}

It can be seen that the word "balï", which has long been used to express the meaning of "city", changed during this period.

\section{THE WORD "KÄNT" THAT IS USED TO EXPRESS THE MEANING OF "CITY"}

Scholars at home and abroad all believe that the word "känt" originates from Sanskrit, and it was originally borrowed from Sanskrit into Sukde, and then borrowed from Sukde into ancient Uighur language. At the beginning, it meant "villages and towns" ${ }^{3}$. In ancient Uighur language, the word "känt" meant "city and hometown" in Persian language is common in the Turkic language today. For example, šäxär in Tucuman language, sagr in the komak language, šähär in Modern Uyghur language, säri in Kazak language, sari in Kyrgyz language and so on are all the same to the word "känt" we are talking about, and they express the same meaning. The word " känt" was also called " kän" in ancient times. In The Encyclopedia of Turk Ethnic Group Languages, "känd" Oguz and the tribal languages close to them mean "village", in most Turkic national languages it meant "city", and the city of Fahrnine called it "Wuzkan", which means "one's own city" ${ }^{5}$. 8) "kän" means city. Kashgar called it "Urdukan", which means "capital", "city of the royal palace, city of the Yellow Emperor and city where the king lives" 6 . From the perspective of the difference of times, The Encyclopedia of Turk Ethnic Group Languages was earlier than Kutadgu Bilig. The Encyclopedia of Turk

\footnotetext{
2 Mahmud Kashgari, The Encyclopedia of Turk Ethnic Group Languages. Xinjiang People's Publishing House, the first printing in January in 2012, page 95 and page 287 in Volume One.

Uginp•Has $• H a j i p$, Kutadgu Bilig, Xinjiang People's Publishing House],2013.11, the first edition

4 Dictionary of Old Uighur: Xinjiang Juvenile Publishing House, 1 st edition in January in1989,page 345.

Mahmud Kashgari, The Encyclopedia of Turk Ethnic Group Languages. Xinjiang People's Publishing House, the first printing in January, 2012, page 262 in Volume One.

Mahmud Kashgari, The Encyclopedia of Turk Ethnic Group Languages. Xinjiang People's Publishing House, the first printing in January, 2012, page 262 in Volume One.
}

Ethnic Group Languages belongs to the initial stage of ancient Uighur language, in which the word "känd" meant "city". In Kutadgu Bilig that was written later than The Encyclopedia of Turk Ethnic Group Languages, "känd" not only meant "city", but also meant administrative regions such as "country". Before this, the word "känd" means "city, county, tribe" and so on, in Kutadgu Bilig, the word "kent" meant "administrative regions smaller than cities and countries". It can be seen that the word "kent" at this time had a narrow range of meanings, which was different from its previous meanings of "city and country", also it was different from its initial meanings of "native place, village".

Taxkand (tashkent, city of stones. page 336 in Vol. I, page 801 in Vol. III in The Encyclopedia of Turk Ethnic Group Languages). This word is commonly seen in Babur's Memoirs and The History of Reside. And at present this city is also one of the civilized cities of the Republic of Uzbekistan. sämär qänd (Samarqand, the Fat City that Persians call "sämärqänd". Page 262 and page 359 in Vol. 1, page 801 in Vol. 3 of The Encyclopedia of Turk Ethnic Group Languages.) This word is commonly seen in Babur's Memoirs (Samarkand owns very good areas and soils, page 79) and The History of Reside. As mentioned above, in The Encyclopedia of Turk Ethnic Group Languages, the word "känt" not only means "city", but also can be combined with words that can express the history, culture and regional characteristics of a place to form a unique territory name.

"yänkänd" is also called" diz ruyin," which means copper city $^{7}$. Many geographical names such as "Samarkand, Tashkent, Wuzkan and Tonkan" that contain "känd" as recorded in The Encyclopedia of Turk Ethnic Group Languages still exist ${ }^{8}$, the word "känd" not only denotes the name of an administrative region alone, but also can be added after the name of other territories to mean place names.

Please clean up the thieves and give the camel caravan safe and smooth going-through conditions.

uluš känd ičindä sän o $\gamma r i \gamma$ arit

ümäg, arqiši $\gamma$ yolida ämin yoit

I heard that you betrayed your friends and family.

yaqin qadaštin yitürmišsän öz

uluš,känd,budundin äwürmišsän yüz

It can be seen from the word "känt" as recorded in Kutadgu Bilig that, in the middle and late period of the Old Uygur language, the range of meaning of the word "känt" was narrowed. It did not mean a city, but meant an administrative area that was smaller than a city.

Mahmud Kashgari, The Encyclopedia of Turk Ethnic Group Languages. Xinjiang People's Publishing House, the first printing in January, 2012, pages 800 and 801 in Volume Three.

Mahmud Kashgari, The Encyclopedia of Turk Ethnic Group Languages. Xinjiang People's Publishing House, the first printing in January, 2012, page 801 in Volume Three. 


\section{THE WORD "HISÂR" THAT IS USED TO EXPRESS THE MEANING OF "CITY"}

From the perspective of language contact, we can see that words such as "känt, balïq, hisâr" appeared simultaneously in literature materials after the 15th century, especially the word" hisâr" was also used. In our language, when we express city, country or this sort of thing, we use the word "hisâr", which is itself a word borrowed from the Arabic language, and it meant castle ${ }^{9}$. The word hisâr came into our language from Arabic language to mean cities and geographical names when we added it to other words. Such geographical names are still in use today.

(1) hisâr: can be seen 42 times in Babur's Memoirs (I left Fergana's territory in Moharan month, went to Horasan, and stopped at a summer ranch in the Hisar region -- Irahay summer ranch, page 189 in Babur's Memoirs). And it can be seen 29 times in The History of Reside.(Rothartan · Yunus Khan also had two other daughters who were born by Sha. Bekwan from Badahashon. The eldest daughter, Rothartan· Nigger- Haneem, and Rothartan· Mahmu Milza who was married to Xisar. Page 238); (2) yangï hisâr: can be seen 25 times in The History of Reside. (After Seidhan took the Ingishal Castle, he turned to Hasihar, page 431); (3) hisâr-i firuzä: can be seen three times in The History of Reside. (It is also said that Hamid Khan Kassa Haile, tax officer of Hisar Firuza, led the army of Hisar Firuza and its nearby places to advance fifteen kurohs to our side.)

These words record the representative works of our ancient times, and we can see that there is a strong mutual influence and acceptance among contemporary nations and countries in different fields. The word "hisâr" is of the same meaning when it is used in words such as šähär, balïq, känt in Uyghur language. Besides expressing the meaning of "city", it can be added to some words to form new geographical names. At that time, the word was widely used, and people at that time had a common understanding of the word. Until now, the word still exists and it can be added to other geographical names to mean the geographical name of some place.

\section{The Name of A Place In MOdern Uyghur LANGUAGE THAT CONTAINS THE WORD KÄNT}

From the above examples, it can be seen that the word "känt" has been used since the beginning of the era of human civilization. The original form of the word "känt" is "kente". It was borrowed from Sanskrit into Sogdian language, and then borrowed from Sogdian language into ancient Uighur language. Originally it meant "villages and towns". Another theory is that the word "känt" was originally borrowed from Yaliyan language, and it was distinguished from the pronunciation of Saizhong language and Tuhuaro language in spoken English after being borrowed into Xinjiang. The word "känt" was used to denote the numeral "100" in these languages according to both the Saizhong language dictionary and the Tuhuaro language dictionary. It can be

A Detailed Dictionary for Chaghatay Language. Xinjiang People's Publishing House, the first printing in April, 2002, page 730. imagined the word "känt" meant "100". In ancient times, after the formation of tribal and family systems, human beings were engaged in a second kind of production, that is, human being were changed from nomadic culture to agricultural culture. Therefore, in order to prevent the threat of wild animals, people began to live together. It can be said that these living conditions formed the original predecessors of the Uygur nationality. According to historical records, the ancient Uighur people were also known as the "ten Uighurs". It is clear that later Uighurs may have been developed from a group of ten people who originally lived together. Therefore, it can be said that they call their tribe in this way to remember their own history. The first few people who lived together developed through history and formed the villages, towns, regions and provinces of today. The word "känt", which means "100", is probably an expression in the large and civilized cities that had been formed later. Some of these cities still exist and some have been destroyed. Although the original meaning of the word has got lost, the geographical names with it as the core still exist.

\section{CONCLUSION}

As mentioned above, the meaning range of the word "känd" that expresses the meaning of "city" is narrower than before in literature classics in ancient Uighur language and Chaghatay Uyghur language. By the time of Chaghatay Uyghur language, the word "känd" not only did not mean city, but also expressed the geographical name of some place when added to other territory nouns.

Judging from the current geographical names, the word "känt" has undergone semantic changes in its long historical development. The word käntt in Modern Uygur language is used to mean the place where the masses live though it is different from the city, the administrative area where farmers live in a centralized way though this area is smaller than a village and so on. As mentioned above, the word känt means both "villages and towns" and "100". In Modern Uygur language, the word känt means a small administrative area. No matter in ancient times when it meant "city" or in modern times when it means "relatively small administrative areas and number", it can be used to form a territory name by being combined with other corresponding words.

The appearance of these words in oral language indicates that cultural exchanges were frequent in this period, so there were more words borrowed from other languages. Therefore, Arabic loanwords such as "hisar" began to be used in the Turkic language to mean "city". Aisjisa means "old, ancient city (photos for place names in Kashi area of Xinjiang Uygur Autonomous Region, page 21) Yinjisa (photos for place names in Kashi area of Xinjiang Uygur Autonomous Region, page 132) As mentioned above, geographical names relative to the word "känt" do not mean the same as in ancient times as "city", "county", "city wall", but it still can be added to many territory names to denote a complete place name. Such geographical names that contain the word "känt" in the modern Uygur language, may be formed with a large city being the core while the word "känt" is included in. If more in-depth research is conducted on this basis, more and more detailed information of research value may be yielded. 


\section{REFERENCES}

[1] The legend of Oghuz Khan, [M], The Ethnic Publishing House 198011, the first edition. (in Chinese)

[2] Dictionary of Old Uighur: Xinjiang Juvenile Publishing House, 198901, 1st edition (in Chinese)

[3] Photocomposed by Dictionary Room of Working Committee on National Languages of Xinjiang Uygur Autonomous Region: Dictionary for Detailed Interpretation of Uygur Language [M], Xinjiang People's Publishing House, 1999-10, 1st printing (in Chinese)

[4] Golden Light Sutra, Xinjiang People's Publishing House [M], 200108 , the first edition (in Chinese)

[5] Kurban Alblimiti, Paritahon Avulahon, Origin of Geographical Names in Xinjiang [M]. Xinjiang University Press, 2001. (in Chinese)

[6] A Detailed Dictionary for Chaghatay Language [M]. Xinjiang People's Publishing House, 2002. (in Chinese)

[7] Denis-Sinor, Selected Works among Inner Asia Studies [M], Zhonghua Book Company, 2006. (in Chinese)

[8] Nigati-Partha. National and Regional Names recorded in " The Encyclopedia of Turk Ethnic Group Languages". Journal of Xinjiang Normal University [J]2006-01. (in Chinese)

[9] Mirza Hayder Doghlat, The History of Reshidi. 2007. (in Chinese)

[10] Babur: Babur's Memoirs [M]. The Ethnic Publishing House, 2010. (in Chinese)

[11] Mahmud Kashgari, The Encyclopedia of Turk Ethnic Group Languages. Xinjiang People's Publishing House [M], 2012. (in Chinese)

[12] Alimjon Mehsut, AdilaAlimjon, Ancient Cities Recorded in " The Encyclopedia of Turk Ethnic Group Languages".[J] Journal of Xinjiang University, 2012. (in Chinese)

[13] Yusuf Has Hajip, Kutadgu Bilig, Xinjiang People's Publishing House[M],2013 (in Chinese)

[14] Arkin Ariz, Erhan Aydin, Old Turkic Inscriptions, [M]. Xinjiang People's Publishing House, 2014 (in Chinese)

[15] Hamit Timur, Abdureop Polat, A detailed Dictionary for Chaghatay Uyghur Language $[\mathrm{M}]$, The Ethnic Publishing House, 2016 (in Chinese) 